\title{
Capecitabine-induced Leukoencephalopathy Presenting with Signs of Transient Ischemic Attack
}

\author{
Geçici İskemik Atak Bulgularıla Prezente Olan Kapesitabine Bă̆lı Lökoensefalopati \\ Olgusu
}

\author{
(1) Sinan Eliaçık, (1) Serdar Aykaç, (1) Funda Uysal Tan \\ Hitit University Faculty of Medicine, Department of Neurology, Corum, Turkey
}

\begin{abstract}
Capecitabine is an oral chemotherapeutic agent used primarily in the treatment of colorectal cancer and breast cancer. With this case report, we aimed to report a patient admitted to the emergency department with stroke-like symptoms as a side effect of capecitabine. Magnetic resonance imaging showed signal changes in the cerebral white matter typical of capecitabine leukoencephalopathy. Since the mechanism of action is not fully understood, clinicians should be aware of this rare complication in order to make appropriate therapeutic decisions.
\end{abstract}

Keywords: Transient ischemic attack, leukoencephalopathy, capecitabine

$\ddot{\mathbf{O z}}$

Kapesitabin, esas olarak kolorektal kanser ve meme kanseri tedavisinde kullanılan oral kemoterapötik bir ajandır. Bu olgu sunumunda acil servise kapesitabinin yan etkisi olarak inme benzeri semptomlarla başvuran bir hasta bildirilmiştir. Beyin manyetik rezonans görüntülemede tipik ak madde lezyonları saptanmıştır. İskemik inme semptomları ile acile gelen hastalarda kliniği taklit edebilecek komorbid durumların da göz önünde bulundurulması tedavi yaklaşımı açısından önemlidir.

Anahtar Kelimeler: Geçici iskemik atak, lökoensafalopati, kapesitabin

\section{Introduction}

A diagnosis of leukoencephalopathy as a side effect of capecitabine was made in the female patient who was admitted to the emergency department with acute severe dysarthria. This rare side effect of capecitabine was presented with a review of the pertinent literature.

\section{Case Report}

A 61-year-old female who had a history of gastric cancer was brought to the emergency room due to a deterioration in speech. Neurological examination didn't reveal any signs other than severe dysarthria. The patient was receiving capecitabine. Diffusion weighted brain magnetic resonance imaging (MRI) showed wide spread symmetrical diffusion restriction bilaterally in basal ganglia, anterolateral thalami, periventricular white matter areas, centrum semiovales, corpus callosum anterior genu and splenium (Figures 1,2). The patient's laboratory findings were not suggestive of metastasis. Electroencephalography, hemogram, routine biochemistry tests including, kidney and liver function tests, electrolyte, and vitamin B12 levels were within normal limits. The patient's complaints improved within the first 10 hours of hospitalization. A diagnosis of toxic multifocal leukoencephalopathy was made based on these clinical and radiological findings. Oxiplatin known to cause posterior reversible encephalopathy syndrome (PRES) was also used in the patient. PRES was ruled out due to current clinical findings in the patient. Cardiomyopathy was not detected. In the followup, the patient had a normal neurological examination, and the diffusion restricting MRI lesions regressed (Figure 3). Contrastenhanced brain MRI was not performed since the initial MRI indicated a leukoencephalopathy condition. Our patient was using a chemotherapeutic agent which could cause these imaging findings. Capecitabine was discontinued and the patient's cancer treatment was revised.

Address for Correspondence/Yazışma Adresi: Lec. Sinan Eliaçık MD, Hitit University Faculty of Medicine, Department of Neurology, Corum, Turkey Phone: +90 5426657563 E-mail: sinaneliacik@gmail.com ORCID: orcid.org/0000-0002-9415-0039

Received/Geliş Tarihi: 05.01.2021 Accepted/Kabul Tarihi: 10.12.2021

${ }^{\circ}$ Copyright 2022 by Turkish Neurological Society

Turkish Journal of Neurology published by Galenos Publishing House. 


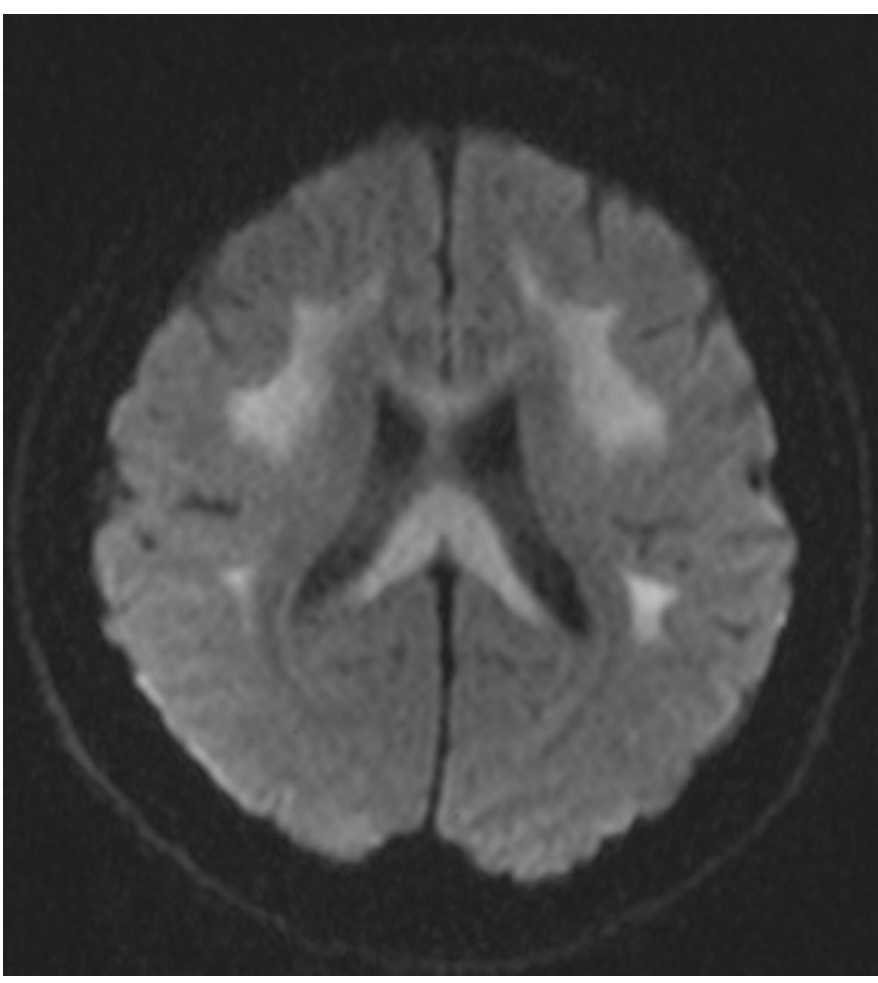

Figure 1. Diffusion magnetic resonance imaging shows bilateral, wide spread symmetrical diffusion restriction in basal ganglia, thalami, periventricular white matter areas, centrum semiovales, corpus callosum anterior genu and splenium

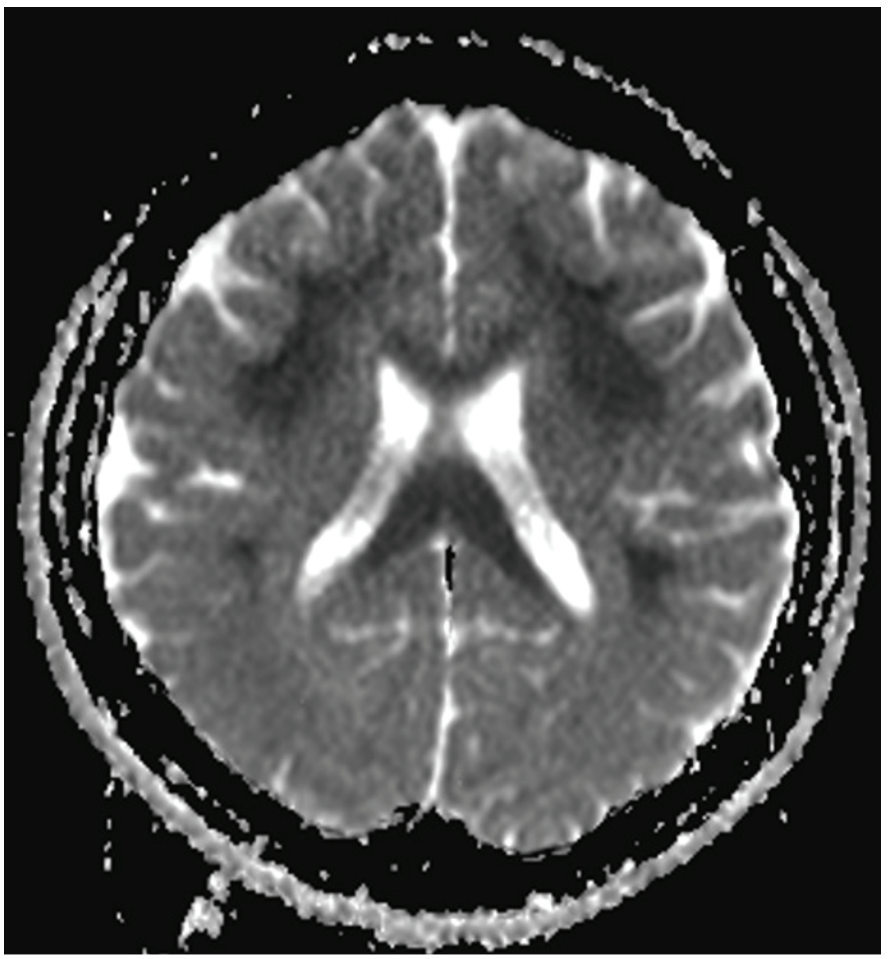

Figure 2. Diffusion weighted imaging and apparent diffusion coefficient map showed widespread symmetrical acute diffusion restriction

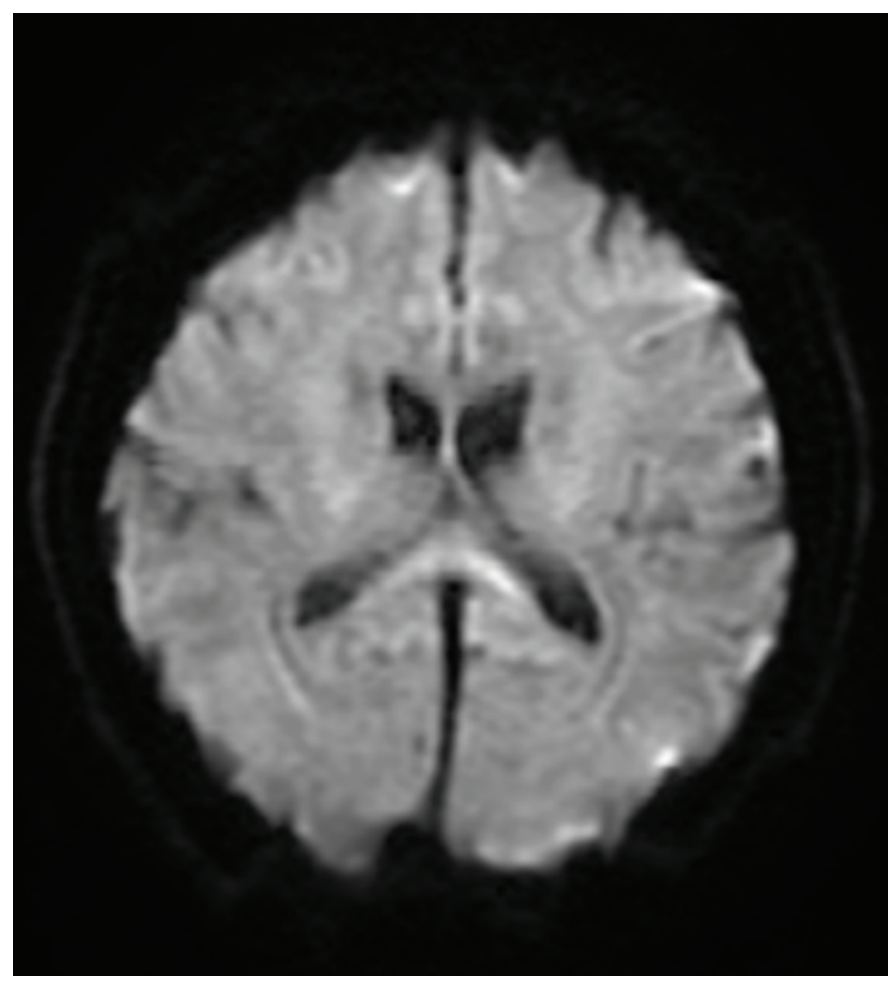

Figure 3. Approximately one week later, radiological findings of diffusion weighted magnetic resonance imaging show regression

Written informed consent was obtained from the patient for this case report.

\section{Discussion}

The patient who was consulted from the emergency department with suspicion of a transient ischemic attack was diagnosed as having leukoencephalopathy according to the imaging findings.

Cancer and stroke have an important role in mortality and morbidity and as life expectancy increases, the incidence of both of these diseases increase. Physicians should be careful while treating both of these chronic diseases in terms of complications that may develop. Although the side effects of the drugs used in cancer treatment are usually temporary, they may become permanent in some patients. However, little is known about the pathogenic mechanisms of chemotherapy-related leukoencephalopathy. Toxicity secondary to antineoplastic agents has been associated with increased permeability of the blood-brain-barrier (BBB). Capecitabine's intermediate metabolite 5-deoxy-5-fluorouridine demonstrates the ability to cross the BBB. Moreover, animal studies showed that 5-fluorouracil (5FU) causes damage to oligodendrocytes, myelin swelling, and macrophage infiltration resulting in restricted movement of free water (1). A study conducted on rats in 2019 demonstrated that 5-FU treatment induced histological alterations in the cerebellum granular layer of rats. In addition, the study showed that 5-FU exhibited significant cytotoxicity to granule cells in rat cerebellum involving oxidative stress and activation of the caspase- 3 pathway (2).

There is a wide spectrum of symptoms in the clinical presentation of capecitabine-induced leukoencephalopathy and differential diagnosis of chemotherapy-related leukoencephalopathy includes 
a variety of conditions. Brain metastasis that could disrupt BBB was excluded in our patient. Other uncommon entities, such as paraneoplastic demyelinating disorders that have similar neuroimaging features were also excluded as they are not reversible and they worsen without treatment (3). Posterior reversible encephalopathy syndrome is characterized clinically by headache, seizures, and altered mental status and radiologically by diffuse hyperintensities in the posterior parietal and occipital white matter areas, although the grey matter can also occasionally be involved. Although PRES is also reversible, such a diagnosis was not probable in this case because of the different clinical characteristics and radiological findings (4).

Early recognition of chemotherapy-related leukoencephalopathy is important, given that discontinuation of the drug is generally associated with clinical and radiological improvement. However, spontaneous recovery has also been reported (5). Capecitabineinduced leukoencephalopathy may correlate with the presence of liver metastases. Among reported patients, more than half of the patients had liver metastases without laboratory evidence of hepatic dysfunction $(6,7)$. However, no metastasis was detected in the imaging tests performed in our patient.

Capecitabine is an oral prodrug of $5-\mathrm{FU}$ and rarely causes leukoencephalopathy $(8,9)$. Capecitabine-induced leukoencephalopathy is treated by the cessation of capecitabine chemotherapy. Excellent recovery upon cessation of capecitabine with no or minimal residual deficit has been reported to occur within several days in all reported patients. In our patient, improvement in MRI findings was observed after about a week. However, there were also patients with irreversible leukoencephalopathy in the literature (10).

Since the mechanism of action is not fully understood, clinicians should be aware of this rare complication in order to make the appropriate therapeutic decisions.

\section{Ethics}

Informed Consent: Written informed consent was obtained from the patient for this case report.

Peer-review: Externally and internally peer-reviewed.

\section{Authorship Contributions}

Surgical and Medical Practices: S.E., S.A., F.U.T., Concept: S.E., Design: S.E., Data Collection or Processing: S.E., S.A., F.U.T., Analysis or Interpretation: S.E., S.A., F.U.T., Literature Search: S.E., S.A., F.U.T., Writing: S.E.

Conflict of Interest: No conflict of interest was declared by the authors.

Financial Disclosure: The authors declared that this study received no financial support.

\section{References}

1. Han R, Yang YM, Dietrich J, et al. Systemic 5-fluorouracil treatment causes a syndrome of delayed myelin destruction in the central nervous system. J Biol 2008;7:12.

2. Zhang Y, Yin N, Liang S, Shen S, Li D, Faiola F. 5-fluorouracil-induced neurotoxicity in rat cerebellum granule cells involves oxidative stress and activation of caspase-3 pathway. Int J Clin Exp Med 2019;12:2334-2343.

3. Sharief U, Perry DJ. Delayed reversible posterior encephalopathy syndrome following chemotherapy with oxaliplatin. Clin Colorectal Cancer 2009;8:163-165.

4. Leypoldt F, Armangue T, Dalmau J. Autoimmune encephalopathies. Ann N Y Acad Sci 2015;1338:94-114.

5. Salmi N, Elghissassi I, Bellahammou K, et al. Atypical reversible leucoencephalopathy syndrome after bevacizumab/folfox regimen for metastatic colon cancer. Case Rep Oncol Med 2014;2014:391256.

6. Yasaki S, Tukamoto Y, Yuasa N, Ishikawa T, Yoshii F. [Late-onset leukoencephalopathy induced by long-term chemotherapy with capecitabine and cyclophosphamide for liver metastasis from breast cancer]. Rinsho Shinkeigaku 2012;52:251-256.

7. Heine A, Schmiedel A, Menschik T, et al. Regression of liver metastases after treatment with oxaliplatin/capecitabine and development of a progressive multifocal leukoencephalopathy in a patient with advanced thymoma. J Clin Oncol 2013;31:e203-e205.

8. Videnovic A, Semenov I, Chua-Adajar R, et al. Capecitabine-induced multifocal leukoencephalopathy: a report of five cases. Neurology 2005;65:1792-1794; discussion 1685 .

9. Obadia M, Leclercq D, Wasserman J, et al. Capecitabine-induced acute toxic leukoencephalopathy. Neurotoxicology 2017;62:1-5.

10. Wagner-Altendorf TA, Heldmann M, Hanssen H, et al. Permanent lesion to the corticospinal tract after therapy with capecitabine. BMJ Case Rep 2019;12:e231248. 